\title{
Observations on spread and fragmentation of blue grama clones in disturbed rangeland
}

\author{
MARILYN J. SAMUEL AND RICHARD H. HART
}

Authors are botanist (retired) and rangeland scientist, USDA-ARS, High Plains Grasslands Research Station, 8408 Hildreth Road, Cheyenne, Wyo. 82009. Samuel's present address is 1203 3rd Street E, Lehigh Acres, Fla. 33936.

\begin{abstract}
Establishment of blue grama (Bouteloua gracilis [H.B.K.] Lag ex. Steud.) depends on adequate precipitation at critical times and on reduced competition from associated vegetation. These conditions rarely occur on Central Plains rangelands. Therefore, rapid vegetative spread of new seedlings is desirable for colonizing disturbed rangeland. Blue grama genotypes selected for rapid spread would also be desirable for rangeland seeding. For 6 years, we followed the rate of spread of 19 blue grama clones originating from seedlings which emerged in 1980 and grew under natural competition. We observed a 4.5 -fold difference in basal area and a 16.3-fold difference in above-ground biomass of these clones, perhaps because of genetic differences among clones and varying levels of competition. Clones must be tested under uniform competition with clonal replication to obtain reliable estimates of their capacity to spread.
\end{abstract}

Key Words: Vegetative reproduction, revegetation, competition, Bouteloua gracilis

Blue grama (Bouteloua gracilis [H.B.K.] Lag ex. Steud.) dominates most of the shortgrass and mixed-grass rangelands of the Great Plains. However, when these rangelands are severely disturbed by plowing, mining, road-building, or other human activities, blue grama may not regain its dominance for decades.

Samuel and Hart (1994) reported that frequency of blue grama on rangeland disturbed 61 years previousiy was less than half that on undisturbed rangeland. Blue grama contributed only about $10 \%$ of the production on disturbed rangeland, compared to 40 to $70 \%$ on undisturbed rangeland.

Reichardt (1982), Costello (1944), and Shantz (1917) found that climax vegetation, characterized by blue grama dominance, may develop on abandoned cropland 20 to 50 years after abandonment. Reichardt concluded that blue grama spread from plants that had survived through the years in which the fields were cultivated, and agreed with Costello (1944) and Hyder et al. (1971, 1975) that establishment of blue grama from seed under the present climatic conditions on shortgrass prairie is highly unlikely. Low seed weight, the potential for only one seminal root per seedling, a limited capacity for water uptake by the seminal root, and a seedling form that places the crown, from which adventitious roots may develop, only a few millimeters below the soil

Send reprint requests to R.H. Hart

Manuscript accepted 9 Feb. 1995. surface contribute to the difficulty of establishing blue grama (Briske and Wilson 1978, Wilson and Briske 1979).

Rapid vegetative spread is advantageous to blue grama plants on a disturbed area, whether they have arisen from seed or have survived the disturbance. Samuel (1985), Green and Goetz (1973), McMillian (1956), Mueller (1941), and Riegel (1940) have reported variability in several growth parameters among blue grama clones from the same location or from locations spread across the Great Plains.

Nevertheless, occasional blue grama seedlings survive and develop into viable plants. Samuel and Hart (1994) found, in 1980, a few blue grama seedlings on an area last disturbed in 1976. These seedlings probably resulted from rare combinations of seed source, suitable amount and timing of precipitation, and reduced competition from existing vegetation (Wilson and Briske 1979; Samuel and Hart 1992; Coffin and Lauenroth 1988, 1989a, 1989b).

We followed the development of 19 blue grama seedlings found on the area of rangeland last disturbed in 1976 to determine the magnitude of differences among plants in rate of spread and fragmentation. We hypothesized that these differences would be larger than the differences observed in the previous study in a cultivated nursery (Samuel 1985), because of greater spatial heterogeneity in competition from other vegetation on the disturbed area.

\section{Materials and Methods}

The study area, described by Samuel and Hart (1994), was on the High Plains Grasslands Research Station in Section 3, T 14 N, $\mathrm{R} 67 \mathrm{~W}$, about $8.5 \mathrm{~km}$ northwest of Cheyenne, Wyo. The area, on Altvan sandy clay loam (Aridic Argiustoll), had been scraped annually from 1966 through 1976 with a road grader, to a depth of $5-10 \mathrm{~cm}$. The disturbed soil was respread over the area after each scraping. Peak standing crop during the growing seasons of 1980 through 1986 ranged from 1.2 to $2.8 \mathrm{Mg} \mathrm{ha}^{-1}$. In 1980 , peak standing crop was approximately $20 \%$ western wheatgrass [Pascopyrum smithii (Rydb.) A. Love], 50\% annual forbs, and $30 \%$ perennial forbs. In 1986 composition of peak standing crop had shifted to approximately $50 \%$ western wheatgrass and $50 \%$ perennial forbs, with traces of annual forbs and other grasses. Total precipitation was $361,445,521,613,514,466$, and 376 $\mathrm{mm}$ in 1980 through 1986, respectively. Average annual precipitation, 1964-1987, was $372 \mathrm{~mm}$. The area was not grazed by livestock during the study. 
Twenty-one seedling blue grama plants were identified, marked, and numbered in the summer of 1980 . As the plants developed, clones 10 and 11 merged and it became impossible to measure them individually, so measurements will be reported for 19 clones.

Each clone was mapped and basal area calculated on 28 April 1981; 23 or 28 September 1981; 9 May 1983; 17 or 20 October $1983 ; 17,21$ or 22 October 1985; and between 29 April and 6 May 1987. Spread on these dates represented spread through the growing seasons of $1980,1981,1982,1983,1984-1985$, and 1986, respectively. We placed a wire grid with a 1.27 by $1.27 \mathrm{~cm}$ spacing over each clone and recorded the number and locations of intersections which lay over the basal area of the plant (Hart 1965). Basal area was calculated from the mean number of intersections recorded on five random placements per clone; each intersection was assumed to represent $1.613 \mathrm{~cm}^{2}$ of basal area. The clone was mapped from the first placement.

On 17-20 October 1983 and 23-24 September 1985, we clipped all herbage from each clone to ground level, dried it at 60 C, and weighed it. In 1985 we also clipped, dried, and weighed all other vegetation inside each blue grama clone and within $0-10$ and $10-20 \mathrm{~cm}$ of the perimeter of each clone. Because a single plant represented each clone, it was not possible to calculate variances of areas or weights.

Above-ground phytomass estimates (y) in 1983 and 1985 were regressed on basal areas ( $\mathrm{x}$ ) after the 1983 and 1985 growing seasons, respectively, using standard methods. Phytomass estimates in 1985 were also regressed on total phytomass of all vegetation $0-10 \mathrm{~cm}$ or $0-20 \mathrm{~cm}$ from the perimeter of each clone, or $0-20$ $\mathrm{cm}$ plus the vegetation within the clone.

\section{Results and Discussion}

Basal area of every clone increased in nearly every year throughout the study. After the 1986 growing season, the basal area of the largest clone, $344 \mathrm{~cm}^{2}$, was 4.5 times that of the smallest clone, $76 \mathrm{~cm}^{2}$ (Fig. 1). In 1983, above-ground phytomass of the heaviest clone was $14.7 \mathrm{~g}$, more than 13 times that of the lightest clone, $1.1 \mathrm{~g}$ (Fig. 1). In 1985, the same clones were still heaviest and lightest and weighed 45.7 and $2.8 \mathrm{~g}$, a 16 -fold difference.

The lightest clone in 1983 and 1985 was also the clone with the least basal area in 1983,1985, and 1986. The heaviest clone in 1983 and 1985 was only seventh in arca in 1983 and eighth in 1985 and 1986. However, the heaviest clone produced $148 \mathrm{mg}$ of phytomass $\mathrm{cm}^{-2}$ of basal area in 1983 and $250 \mathrm{mg} \mathrm{cm}^{-2}$ in 1985 , while the clone with the greatest area produced only 72 and 122 $\mathrm{mg} \mathrm{cm}^{-2}$ in 1983 and 1985 , respectively. Phytomass of clones was more closely correlated with basal area in $1983\left(\mathrm{r}^{2}=0.67\right)$ than in $1985\left(r^{2}=0.57\right)$.

Competition from associated vegetation is an important factor influencing rate of spread. After 3 growing seasons, blue grama seedlings transplanted into $16-\mathrm{cm}$ openings in a western wheatgrass sod averaged $1.04 \mathrm{~g}$ of phytomass (standard error $=0.19$ ), vs. $0.20 \mathrm{~g}$ of phytomass (standard error $=0.05$ ) from seedlings transplanted into very small openings in otherwise undisturbed sod (Samuel and Hart 1992).

When competition is lacking, the range in phytomass and basal area is much smaller. Samuel (1985) selected 5 'slow-spreading' clones, which had spread only a few centimeters in an area plowed 50 years earlier, and 5 'fast-spreading' clones, which had developed into large plants within the same plowed area. In the fourth year of growth in a cultivated nursery, an average of $104 \mathrm{~g}$ (range 82-142 g) of above-ground phytomass was harvested from fast-spreading clones vs. an average of $93 \mathrm{~g}$ (range 82-130 g) from slow-spreading clones.

We did not estimate competition until 1985, when phytomass of blue grama clones was not correlated with phytomass of associated vegetation in any of the 3 zones measured (data not shown). If phytomass of associatcd vegetation had been measured in the first 1 or 2 years of establishment, some correlation might have been detected.

Often, as the clones increased in size, older stems near the centers of the clones died, creating bare spots. Clone 80-1 showed the common pattern of bare areas opening and closing as the clone spread (Fig. 2). Clone 80-21 fragmented as it spread, partially because a rock and a developing clone of prairie junegrass

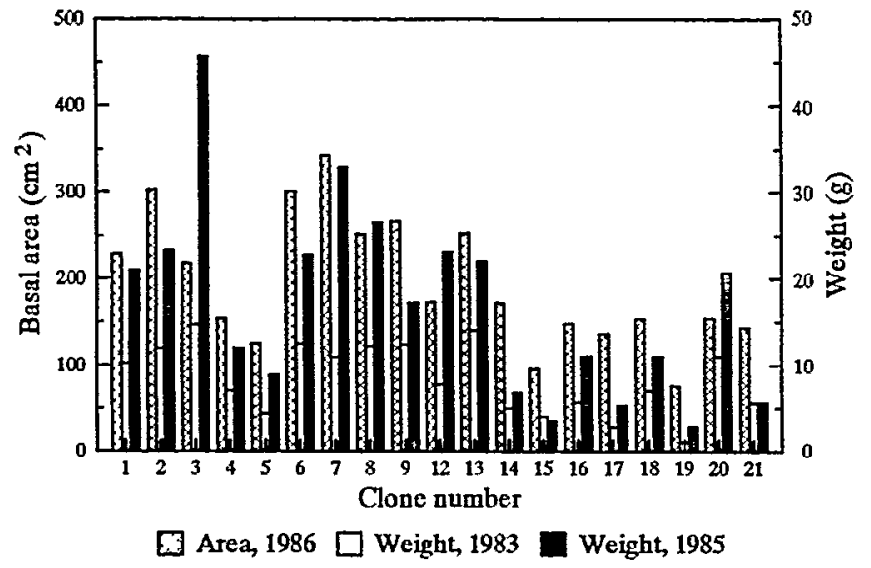

Fig. 1. Basal area at the end of the 1986 growing season, and dry weight of above-ground phytomass at the ends of the 1983 and 1985 growing seasons, of 19 blue grama clones arising from seedlings established in 1980 .

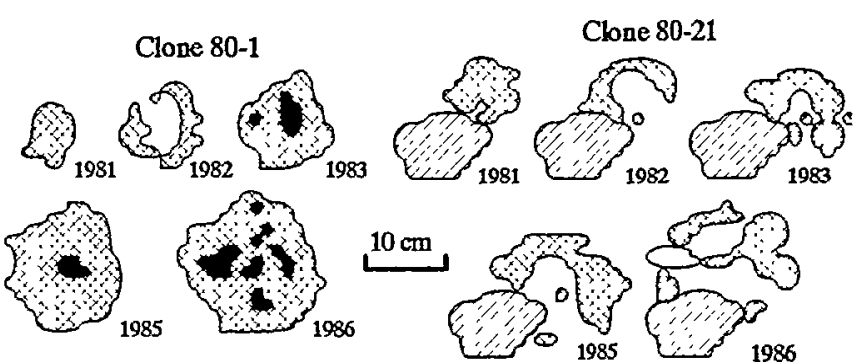

Blue grama $\square$ junegrass $\square$ Rock $\square$ Bare ground

Fig. 2. Basal area of 2 blue grama clones, showing development of internal bare areas and fragmentation, at the ends of the 19811986 growing seasons. 
(Koeleria cristata [L.] Pers.) interfered with spread and reunion of the fragments.

Fragmentation of clones has been documented as a means of spread in New Zealand fescue (Festuca novae-zelandiae Cockayne) (Lord 1993), sheep fescue (Festuca ovina L.) (Harberd 1962), German velvetgrass (Holcus mollis L.) (Harberd 1967), tufted hairgrass (Deschampsia caespitosa [L.] Beauv.) (Davy 1980, Gatsuk et al. 1980), and moor matgrass (Nardus stricta L.) (Chadwick 1960). Lord (1993) determined the identity of New Zealand fescue tussocks by isozyme electrophoresis, and found clonal fragments separated by as much as $2.7 \mathrm{~m}$, in a stand estimated to be 500 years old. An annual spread of $3 \mathrm{~mm}$ would be adequate to produce separation at this distance. Maximum width of blue grama clone $80-21$ was $18 \mathrm{~cm}$, representing a spread of $3 \mathrm{~cm} \mathrm{yr}^{-1}$ for 6 years from the original center.

In conclusion, a great deal of variability in rate of spread exists among blue grama clones, and this may be exaggerated by differences in levels of competition. We observed a 4.5-fold difference in basal area and a 16.3-fold difference in above-ground phytomass of blue grama clones growing under natural competition. Clones must be tested under uniform competition to obtain reliable estimates of their capacity to spread. Replicated testing of vegetative propagules (clonal ramets) would further improve reliability in measuring rate of spread.

\section{Literature Cited}

Briske, D.D., and A.M. Wilson. 1978. Moisture and temperature requirements for adventitious root development in blue grama seedlings. J. Range Manage. 31:174-178.

Chadwick, M.J. 1960. Nardus stricta, a weed of hill grazings, p. 246-256. In: J.L. Harper (ed.), The Biology of Weeds. Brit. Ecol. Soc. Symp. No. 1. Blackwell Sci. Publ., Oxford.

Coffin, D.P., and W.K. Lauenroth. 1988. The effects of disturbance size and frequency on a shortgrass plant community. Ecology 69:1609-1617.

Coffin, D.P., and W.K. Lauenroth. 1989a. Small-scale disturbances and the successional dynamics in a shortgrass plant community: Interactions of disturbance characteristics. New Phytol. 67:258-286.

Coffin, D.P., and W.K. Lauenroth. 1989b. Spatial and temporal variation in the seed bank of a semiarid grassland. Amer. J. Bot. 76:53-58.

Costello, D.F. 1944. Natural revegetation of abandoned plowed land in the mixed prairie association of northeastern Colorado. Ecology 25:312-326.

Davy, A.J. 1980. Biological flora of the British Isles No. 149, Deschampsia caespitosa (L.) Beauv. J. Ecol. 68:1075-1096.

Gatsuk, L.E., O.V. Smirnova, L.I. Vorontzova, L.B. Zangolnova, and L.A. Zhukova. 1980. Age states of plants of various growth forms: a review. J. Ecol. 68:675-696.

Green, C.E., and H. Goetz. 1973. Morphological variation in three ecotypes of Agropyron smithii Rydb. and Bouteloua gracilis (H.B.K.) Lag ex. Steud. North Dakota State Agr. Exp. Sta. Bull. 491.

Harberd, D.J. 1962. Some observations on natural clones in Festuca ovina. New Phytol. 61:85-100.

Harberd, D.J. 1967. Observations on natural clones in Holcus mollis. New Phytol. 66:401-408.

Hart, R.H. 1965. A miniature grid for estimating area of grass leaves. Agron. J. 57:634.

Hyder, D.N., R.E. Bement, E.E. Remmenga, and D.F. Harvey. 1975. Ecological responses of native plants and guidelines for management of shortgrass range. USDA Tech. Bull. 1503, U.S. Government Printing Office, Washington, D.C.

Hyder, D.N., A.C. Everson, and R.E. Bement. 1971. Seedling morphology and seedling failures with blue grama. J. Range Manage. 24:287-292.
Lord, J.M. 1993. Does clonal fragmentation contribute to recruitment in Festuca novae-zelandiae? New Zealand J. Bot. 31:133-138.

McMillian, C. 1956. Nature of the plant community. 1. Uniform garden and light period studies of five grass taxa in Nebraska. Ecol. 37:330-340.

Mueller, I.M. 1941. An experimental study of thizomes of certain prairie plants. Ecol. Monogr. 11:165-188.

Reichardt, K.L. 1982. Succession of abandoned fields on the shortgrass prairie, northeastern Colorado. Southwest. Nat. 27:299-304.

Riegel, A. 1940. A study of the variations in the growth of blue grama grass from seed produced in various sections of the Great Plains region. Trans. Kansas Acad. Sci. 43:155-171.

Samuel, M.J. 1985. Growth parameter differences between populations of blue grama. J. Range Manage. 38:339-342.

Samuel, M.J., and R.H. Hart. 1992. Survival and growth of blue grama seedlings in competition with western wheatgrass. J. Range Manage. 45:444-448.

Samuel, M.J., and R.H. Hart. 1994. Sixty-one years of secondary succession on rangelands of the Wyoming High Plains. J. Range Manage. 47:184-191.

Shantz, J.L. 1917. Plant succession on abandoned roads in eastern Colorado. J. Ecol. 5:19-42.

Wilson, A.M., and D.D. Briske. 1979. Seminal and adventitious root growth of blue grama seedlings in the Central Plains. J. Range Manage. 32:209-213. 